\title{
Actinonin, a meprin A inhibitor, protects the renal microcirculation during sepsis
}

\author{
Zhen Wang ${ }^{\star}$, Christian Herzog ${ }^{\dagger}$, Gur P. Kaushal ${ }^{\dagger}$, Neriman Gokden ${ }^{\ddagger}$, and Philip R. Mayeux ${ }^{\star}$ \\ *Department of Pharmacology and Toxicology, University of Arkansas for Medical Sciences, Little \\ Rock, Arkansas \\ tDepartment of Medicine, Division of Nephrology, University of Arkansas for Medical Sciences, \\ Little Rock, Arkansas \\ ¥Department of Pathology, University of Arkansas for Medical Sciences, Little Rock, Arkansas
}

\begin{abstract}
Sepsis-induced acute renal injury (AKI) occurs in $20 \%-50 \%$ of septic patients and nearly doubles the mortality rate of sepsis. Since treatment in the septic patient is usually only begun after the onset of symptoms, therapy that is effective even when delayed would have the greatest impact on patient survival. The metalloproteinase meprin A, an oligomeric complex made of $\alpha$ - and $\beta$ subunits, is highly expressed at the brush-border membranes of the kidney and capable of degrading numerous substrates including extracellular matrix proteins and cytokines. The goal of the present study was to compare the therapeutic potential of actinonin, an inhibitor of meprin A when administered before and after the onset of sepsis. Mice were treated with actinonin at $30 \mathrm{~min}$ prior to or $7 \mathrm{~h}$ post induction of sepsis by cecal ligation and puncture (CLP). Intravital videomicroscopy was utilized to image renal peritubular capillary perfusion and reactive nitrogen species. Actinonin treatment 30 min before CLP reduced IL1- $\beta$ levels and prevented the fall in renal capillary perfusion at $7 \mathrm{~h}$ and $18 \mathrm{~h}$. Actinonin also prevented the fall in renal capillary perfusion even when administered at $7 \mathrm{~h}$ post CLP. In addition, even late administration of actinonin preserved renal morphology and lowered blood urea nitrogen and serum creatinine concentrations. These data suggest that agents like actinonin should be evaluated further as possible therapeutic agents because targeting both the early systemic and later organ-damaging effects of sepsis should have the highest likelihood of success.
\end{abstract}

\section{Keywords}

intravital microscopy; reactive nitrogen species; cecal ligation and puncture; acute kidney injury; renal capillary

\section{INTRODUCTION}

Sepsis is a disorder initiated by excessive activation of innate immunity. It is a serious medical problem particularly in patients in the intensive care unit (ICU) 1 where it is the

Corresponding Author: Philip R. Mayeux, Ph.D., Department of Pharmacology and Toxicology, University of Arkansas for Medical Sciences, 4301 West Markham Street, \# 611, Little Rock, AR 72205, 501-686-8895, 501-686-5521 fax, prmayeux@uams.edu.

Publisher's Disclaimer: This is a PDF file of an unedited manuscript that has been accepted for publication. As a service to our customers we are providing this early version of the manuscript. The manuscript will undergo copyediting, typesetting, and review of the resulting proof before it is published in its final citable form. Please note that during the production process errors may be discovered which could affect the content, and all legal disclaimers that apply to the journal pertain. 
second leading cause of death in non-coronary ICU patients $(1,2)$. Acute renal injury (AKI) occurs in $20 \%-50 \%$ of septic patients and nearly doubles the mortality rate of sepsis (3). Since current therapy is mostly supportive and largely ineffective (4), there is a critical need to uncover new therapeutic approaches because the incidence of sepsis-induced AKI is predicted to increase as the population ages. Moreover, there is growing recognition of the need for treatment regimens that target both the early systemic and later kidney-specific effects of sepsis because it is clear now that goal-directed multiple-approach therapy has the greatest chance for success (4).

In murine sepsis models of AKI, peritubular capillary perfusion is dramatically reduced during the development of sepsis resulting in a pro-oxidant tubular microenvironment that culminates in tubular injury and decreased renal function (5-8). There is growing evidence to show that changes in the renal capillary-tubule microenvironment can lead to tubular injury and disrupt renal function in a variety of other acute insults such as ischemia/ reperfusion (9) and cisplatin toxicity (10). Actinonin, a potent inhibitor of the meprin family of zinc-dependent metalloproteinases with selectivity toward meprin A, has been reported to have protective effects against ischemia/reperfusion (11), cisplatin (10) and sepsis-induced renal injury (12).

Meprins are an oligomeric complex made of $\alpha$ - and/or $\beta$ - subunits and are highly expressed at the brush-border membranes of epithelial cells of the kidney and intestines. Meprin A, the heterooligomeric comprised of both $\alpha$ - and $\beta$ - subunits is the predominant form of meprin expressed in the apical membranes of renal proximal tubules and is estimated to comprise as much as $5 \%$ of the total brush-border membrane proteins in the murine kidney $(13,14)$. This proteinase is capable of degrading not only bioactive peptides such as gastrin and bradykinin, but also extracellular matrix proteins such as laminin, fibronectin, collagen IV and nidogen $(13,15)$. Meprins are also capable of proteolytically processing cytokines and chemokine. For example, meprin A and meprin $\alpha$ are capable of generating biologically active IL- $1 \beta$ from its precursor pro-IL-1 $\beta$ (16) This suggest that meprin may play a critical role in the inflammatory response as well as in local tissue injury.

A recent paper by Yura, et al. (17) showed that meprin- $\alpha$ knockout mice were protected against lipopolysaccharide (LPS)-induced AKI. This finding supported a report by Holly et al. (12) showing that actinonin administered at the time of induction of sepsis by cecal ligation and puncture (CLP) in mice reduced renal injury. However, this study did not address the mechanism of protection. The goal of the present study was to examine the effects of actinonin on two key factors contributing to renal injury, capillary perfusion and tubular epithelial injury, and to compare the therapeutic potential of actinonin when administered before and after the onset of sepsis. The latter is especially important because the timing of therapy in the septic patient is recognized to be absolutely critical to its success, particularly with regard to the development of renal failure (18) and since treatment in the septic patient is usually begun only after the onset of symptoms (i.e., systemic inflammatory response syndrome) (19). Our results in the murine model of CLP-induced AKI show that actinonin not only prevents the early decline in peritubular capillary perfusion but also restores capillary perfusion and prevents tubular oxidant generation when administered even after the onset of sepsis.

\footnotetext{
${ }^{1}$ Non-standard abbreviations: Intensive care unit, ICU; AKI, acute kidney injury; CLP, cecal ligation and puncture; RNS, reactive nitrogen species; actinonin, 3-[[1-[(2-(hydroxymethyl)-1-pyrrolidinyl)carbonyl]-2-methylpropyl]carbamoyl]octanohydroxamic acid; FITC-dextran, fluorescein isothiocyanate-dextran; DHR, 2-(3,6-diamino-9H-xanthen-9-yl)-benzoic acid, methyl ester; LPS, lipopolysaccharide; IVVM, intravital videomicroscopy; NOx, nitrate + nitrite; PAS, periodic acid-Schiff; BUN, blood urea nitrogen; $\mathrm{RBC}$, red blood cell
} 


\section{MATERIALS AND METHODS}

\section{Reagents}

3-[[1-[(2-(Hydroxymethyl)-1-pyrrolidinyl)carbonyl]-2-

methylpropyl]carbamoyl]octanohydroxamic acid (actinonin) and fluorescein isothiocyanatedextran 500,000 Da conjugate (FITC-dextran) were purchased from Sigma-Aldrich (St. Louis, MO). 2-(3,6-diamino-9H-xanthen-9-yl)-benzoic acid, methyl ester (dihydrorhodamine 123, DHR) was purchased from Invitrogen (Eugene, OR).

\section{Mouse model of cecal ligation and puncture-induced AKI}

CLP-induced sepsis was performed as described previously (20) with modifications that lead to more consistent development of AKI by using older male mice $(6,21)$. Male C57/BL6 mice (Harlan, Indianapolis, IN) at 39 to 40 week of age were acclimated for 1 week with free access to food and water. At the time of surgery, the mice were anesthetized using isoflurane inhalation. After laparotomy, a 4-0 silk ligature was placed $1.5 \mathrm{~cm}$ from the cecal tip. The cecum was punctured twice with a 21 -gauge needle and gently squeezed to express approximately a $1 \mathrm{~mm}$ column of fecal material (CLP mice). In Sham mice, the cecum was located but neither ligated nor punctured. The abdominal incision was closed in two layers with 4-0 silk sutures. After surgery, $1 \mathrm{ml}$ of warmed normal saline was administered into the intraperitoneal cavity. After recovering from anesthesia, mice were placed in individual cages and set on a warming pad. Mice studied at $18 \mathrm{~h}$ post CLP received imipenem/cilastatin $(14 \mathrm{mg} / \mathrm{kg}$, s.c.) in $1.5 \mathrm{ml}$ of two-thirds normal saline $(40 \mathrm{ml} / \mathrm{kg}$ ) for fluid resuscitation (21, 22 ) at $6 \mathrm{~h}$ post CLP. Survival at $18 \mathrm{~h}$ post CLP was 100\%. All animals were housed and killed in accordance with the National Institutional of Health Guide for the Care and Use of laboratory Animals and with approval of the University of Arkansas for Medical Sciences Institutional Animal Care and Use Committee.

\section{Intravital videomicroscopy (IVVM)}

Mice were anesthetized with isoflurane and the left kidney was exposed by a flank incision. The kidney was positioned on a glass stage above a Zeiss Axiovert 200 inverted fluorescence microscope equipped with an Axiocam HSm digitizing camera (Zeiss, Jena, Germany) and kept moist with saline and covered. During the entire IVVM procedure, core temperature was monitored via a rectal temperature probe and maintained at $36^{\circ} \mathrm{C}$ to $37^{\circ} \mathrm{C}$ using an infrared heat lamp. At the end of IVVM, blood was collected from inferior vena cava and the mouse was killed by cervical dislocation. The right kidney was fixed in $10 \%$ phosphate-buffered formalin.

\section{Actinonin treatment}

The meprin A inhibitor, actinonin $(23,24)$, was evaluated at a dose of $20 \mathrm{mg} / \mathrm{kg}$ in $10 \mathrm{ml} / \mathrm{kg}$ vehicle (5\% ethanol in saline, i.p.). This dose was based on our previous studies $(10,16)$ and study showing complete inhibition of meprin A activity in the kidney $3 \mathrm{~h}$ following i.p. dosing (25). Mice were treated with actinonin or vehicle $30 \mathrm{~min}$ prior to CLP (Act $(-0.5 \mathrm{~h}$ ) group) or at $7 \mathrm{~h}$ post CLP (Act (+7h) group). Treatment with actinonin at $7 \mathrm{~h}$ post CLP was chosen for delayed treatment because this time is after the initial decline in renal capillary perfusion but before the generation of RNS in the kidney and the appearance of renal tubular epithelial damage (6). In separate studies, groups of mice treated with or without vehicle at $30 \mathrm{~min}$ prior to or $7 \mathrm{~h}$ post Sham or CLP surgery showed no differences in capillary perfusion at $18 \mathrm{~h}$ respectively. Therefore, the Sham $(-0.5 \mathrm{~h})$ and Sham $(+7 \mathrm{~h})$ vehicle groups are represented by the Sham $18 \mathrm{~h}$ group and the CLP $(-0.5 \mathrm{~h})$ and CLP $(+7 \mathrm{~h})$ vehicle groups are represented by the CLP $18 \mathrm{~h}$ group in Figs. 4-7. 


\section{Evaluation of renal peritubular capillary perfusion}

At $10 \mathrm{~min}$ before IVVM, mice were administered FITC-dextran (500,000 Da, $2 \mu \mathrm{mol} / \mathrm{kg}$ ) and DHR $(1.1 \mathrm{mg} / \mathrm{kg})$ in a total volume of $3 \mathrm{ml} / \mathrm{kg}$ via the penile vein. During IVVM, the renal intravascular space and red blood cell (RBC) movements were visualized with FITCdextran using an excitation of $470 \mathrm{~nm}$ and an emission of $520 \mathrm{~nm}$. For each mouse, five videos of $10 \mathrm{~s}$ each were captured at approximately 30 frames per second from five randomly selected fields of view $(\times 200)$. Capillary perfusion was analyzed as described previously (6). Briefly, approximately 150 randomly selected vessels per mouse were classified into three categories of blood perfusion: "Continuous Flow," whereby RBC movement in the vessel was not interrupted during the video; "Intermittent Flow," whereby RBC movement stopped or reversed any time during the video; and "No Flow," whereby no RBC movement was detected. Data were expressed as the percentage of vessels in each of the three categories.

\section{Evaluation of renal tubular epithelial cell RNS generation using IVVM}

DHR is oxidized to fluorescent rhodamine preferentially by the RNS, peroxynitrite (26). Rhodamine fluorescence was visualized at $535 \mathrm{~nm}$ excitation and $590 \mathrm{~nm}$ emission and captured during IVVM from five randomly selected fields of view $(\times 200)$ using a $500 \mathrm{~ms}$ exposure. Fluorescence intensity of each image was quantified using AxioVision Image Software (Zeiss, Jena, Germany) after first subtracting background fluorescence intensity. Data were expressed as arbitrary units per $\mu \mathrm{m}^{2}$.

\section{Evaluation of renal tubular epithelial cell redox stress using IVVM}

$\mathrm{NAD}(\mathrm{P}) \mathrm{H}$ autofluorescence was used as an indicator of cellular redox stress $(27,28)$. $\mathrm{NAD}(\mathrm{P}) \mathrm{H}$ autofluorescence was visualized at $365 \mathrm{~nm}$ excitation and $420 \mathrm{~nm}$ emission and captured from five randomly selected fields of view $(\times 200)$ using a $500 \mathrm{~ms}$ exposure. Fluorescence intensity of each image was quantified using AxioVision Image Software (Zeiss, Jena, Germany) after first subtracting background fluorescence intensity. Data were expressed as arbitrary units per $\mu \mathrm{m}^{2}$.

\section{Serum IL-1 $\beta$ and TNF- $\alpha$ levels}

Serum IL-1 $\beta$ and TNF- $\alpha$ levels were determined using a mouse cytokine MILLIPLEX MAP Kit (Millipore, Billerica, MA). IL- $1 \beta$ and TNF- $\alpha$ levels were expressed as $\mathrm{pg} / \mathrm{ml}$.

\section{Serum nitrate/nitrite levels}

Serum nitrate/nitrite (NOx) levels in the serum were determined using the Total Nitric Oxide Assay Kit (Assay Designs, Ann Arbor, MI) as directed by the manufacturer. Briefly, nitrate in serum samples was converted to nitrite using nitrate reductase followed by the colorimetric detection of nitrite as a colored azo dye product of the Griess reaction. Data were expressed as serum NOx concentration in $\mu \mathrm{M}$.

\section{Renal tubular injury score}

Paraffin-embedded sections ( $3 \mu \mathrm{m}$ ) were prepared from kidneys fixed in 10\% phosphatebuffered formalin. The periodic acid-Schiff (PAS) stain was used for the analysis of morphology with light microscopy (Nikon E800, Nikon, Inc., Melville, NY). Sections were scored in a blinded, semi-quantitative manner using an established scoring scale (29). For each animal, at least 10 high power (400x) fields were examined. The percentage of tubules that displayed cellular necrosis, loss of brush border, cast formation, vacuolization, and tubule dilation were scored as follows: $0=$ none, $1=<10 \%, 2=11-25 \%, 3=26-45 \%, 4=$ $46-75 \%$, and $5=>76 \%$. 


\section{Serum blood urea nitrogen and creatinine}

Blood urea nitrogen (BUN) and creatinine concentrations in serum were measured using the QuantiChrom ${ }^{\mathrm{TM}}$ Urea Assay kit and Creatinine Assay kit respectively (BioAssay Systems, Hayward, CA). Data were expressed as serum BUN concentration in $\mathrm{mg} / \mathrm{dl}$ and serum creatinine concentration in $\mathrm{mg} / \mathrm{dl}$.

\section{Statistical analysis}

Data were analyzed using Prism 5.0c for Mac (GraphPad Software Inc., San Diego, CA) and presented as mean \pm S.E.M. Data with three or more groups were analyzed using a one-way ANOVA followed by the Bonferroni post test. Renal tubular injury scores were analyzed by using the non-parametric Kruskal-Wallis test followed by Dunn's multiple comparison test. A $p$ value $<0.05$ was considered significant.

\section{RESULTS}

\section{Actinonin Decreased Serum IL-1 $\beta$ Levels But Not TNF- $\alpha$ Levels at $7 \mathrm{~h}$ Post CLP}

Following induction of sepsis by CLP, there is an initial increase in cytokines within the first few hours $(21,30)$. IL-1 $\beta$ and TNF- $\alpha$ are two major pro-inflammatory cytokines that participate in the development of sepsis-induced AKI. At $7 \mathrm{~h}$ post CLP, serum IL-1 $\beta$ levels were significantly increased at $7 \mathrm{~h}$ post CLP (Fig. 1A, $p<0.05$ compared to Sham mice). Actinonin treatment $0.5 \mathrm{~h}$ prior to CLP lowered serum IL-1 $\beta$ levels compared to CLP alone $(p<0.05)$. Actinonin treatment had no effect on the increase in serum TNF- $\alpha$ levels at $7 \mathrm{~h}$ post CLP (Fig. 1B). These data suggest that meprin activation contributes, at least in part, to the early increase in IL-1 $\beta$.

\section{Actinonin Protected Against Capillary Dysfunction at $7 \mathrm{~h}$ Post CLP}

To assess the effects of actinonin on renal cortical capillary perfusion following induction of sepsis, three groups of mice (Sham, CLP 7h and CLP 7h + Act $(-0.5 \mathrm{~h})$ ) underwent IVVM with FITC-dextran. Renal cortical peritubular capillary perfusion was dramatically reduced at $7 \mathrm{~h}$ post CLP compared to Sham (Fig. 2). The percentage of vessels with Continuous Flow decreased from $84 \pm 9 \%$ in Sham to $54 \pm 4 \%$ in CLP $7 \mathrm{~h}(p<0.05)$ and vessels with No Flow increased from $6 \pm 2 \%$ in Sham to $25 \pm 4 \%$ in CLP $(p<0.05)$. Administration of actinonin $0.5 \mathrm{~h}$ prior to CLP prevented the early decline in capillary perfusion $(p<0.05$ compared to CLP 7h).

\section{Actinonin Reduced Renal Tubular Epithelial Cell Redox Stress at $7 \mathrm{~h}$ Post CLP}

Tubular cell $\mathrm{NAD}(\mathrm{P}) \mathrm{H}$ autofluorescence, an indicator of cellular redox stress, was measure by IVVM. NAD(P)H autofluorescence intensity increased at $7 \mathrm{~h}$ post CLP (Fig. 3), a time when capillary perfusion was greatly reduced. Actinonin treatment at $0.5 \mathrm{~h}$ prior to CLP prevented the rise in $\mathrm{NAD}(\mathrm{P}) \mathrm{H}$ autofluorescence $(p<0.05$ compared to CLP $7 \mathrm{~h})$ suggesting that actinonin not only preserved capillary perfusion but also decreased tubular redox stress induced by CLP.

\section{Effects of Pretreatment or Delayed Treatment with Actinonin on Capillary Dysfunction at $18 \mathrm{~h}$ Post CLP}

Renal peritubular capillary perfusion was assessed at $18 \mathrm{~h}$ post CLP in mice. Actinonin was administered at $30 \mathrm{~min}$ prior to CLP group or at $7 \mathrm{~h}$ post CLP. Fig. 4 shows that the percentage of perfused cortical peritubular capillaries was significantly decreased in the CLP $18 \mathrm{~h}$ group compared to the Sham $18 \mathrm{~h}$ group $(p<0.05)$. Actinonin pre-treatment (CLP 18h + Act $(-0.5 \mathrm{~h})$ ) prevented the decline in capillary perfusion. More importantly, delayed treatment $($ CLP $18 \mathrm{~h}+$ Act $(+7 \mathrm{~h}))$ with actinonin also prevented the decline in peritubular 
capillary perfusion ( $p<0.05$ compared to CLP 18h). These finding indicate that when actinonin was administered at $7 \mathrm{~h}$ post CLP, a time when capillary perfusion was already decreased (Fig. 2), actinonin was actually able to restore capillary perfusion.

\section{Actinonin Reduced Tubular Epithelial Cell RNS Generation But Not Systemic NO Generation}

Our previous studies showed that the decline in renal capillary perfusion caused by sepsis is associated with RNS generation by the renal tubules $(6,7)$. To assess the effects of actinonin on renal tubular epithelial cell RNS generation after CLP, we monitored rhodamine fluorescence (26) at $18 \mathrm{~h}$ post CLP in mice treated with actinonin $30 \mathrm{~min}$ prior to CLP or at $7 \mathrm{~h}$ post CLP. Representative images captured during IVVM of FITC-dextran and rhodamine fluorescence in the same fields of view are shown in Fig. 5A-H. Rhodamine fluorescence was increased in tubules bordered by capillaries with compromised flow. Both treatments with actinonin increased capillary perfusion and decreased rhodamine fluorescence. The analyses of rhodamine fluorescence density from these groups of mice are presented in Fig. 6A. Mean rhodamine fluorescence increased significantly at CLP $18 \mathrm{~h}$ compared to Sham 18h (Fig. 6A, $p<0.05$ ) indicating RNS generation in renal tubular cells. Both pre- and delayed treatment with actinonin reduced in rhodamine fluorescence density, indicating a reduction in RNS generation by renal tubules ( $p<0.05$ compared to CLP 18h). Serum NOx levels were used as a marker of systemic NO generation. NOx levels (Fig. 6B) were significantly elevated at CLP $18 \mathrm{~h}$ compared to Sham $18 \mathrm{~h}(p<0.05)$. Neither pre- nor delayed treatment with actinonin had any effect on serum NOx level at $18 \mathrm{~h}$ post CLP.

\section{Actinonin Decreased Serum IL-1 $\beta$ and TNF- $\alpha$ Levels at $18 \mathrm{~h}$ Post CLP}

To compare the effects of the two dosing regimens of actinonin treatment on serum IL-1 $\beta$ and TNF- $\alpha$ levels at $18 \mathrm{~h}$ post CLP, serum was collected from Sham, CLP 18h, CLP $18 \mathrm{~h}+$ Act $(-0.5 \mathrm{~h})$ and CLP $18 \mathrm{~h}+$ Act $(+7 \mathrm{~h})$ groups. Fig. 7A shows that both pre- and delayed treatment with actinonin significantly decreased serum IL-1 $\beta$ levels compared to CLP $18 \mathrm{~h}$ ( $p$ $<0.05)$. Fig. 7B shows that serum TNF- $\alpha$ levels were significantly decreased at $18 \mathrm{~h}$ post CLP only when mice received pretreatment with actinonin ( $p<0.05$ compared to CLP 18h).

\section{Effects of Pretreatment or Delayed Treatment with Actinonin on Renal Morphology and Serum Levels of BUN and Creatinine}

Representative images from PAS-stained kidney tissue sections from Sham, CLP 18h, CLP $18 \mathrm{~h}+$ Act $(-0.5 \mathrm{~h})$ and CLP $18 \mathrm{~h}+$ Act $(+7 \mathrm{~h})$ groups are shown in Fig. 8A-D respectively. The CLP $18 \mathrm{~h}$ group showed relatively mild morphological damage characterized by mild brush-border loss, tubular degeneration and vacuolization in the early segments of proximal tubules. Both pre- and delayed treatment with actinonin reduced the morphological changes and the tubular injury score (Fig. 8E, $p<0.05$ compared to CLP 18h) as well as serum BUN levels (Fig. 8F, $p<0.05$ ). Delayed treatment with actinonin significantly reduced serum creatinine concentration (Fig. 8G, $p<0.05$ ). These data indicate that actinonin reduced both morphological and functional renal injury.

\section{DISCUSSION}

Timing of therapy in the septic patient is recognized to be absolutely critical to its success (4). This is particularly important with regard to the development of AKI since treatment in the septic patient is usually begun only after the onset of symptoms (i.e., systemic inflammatory response syndrome) $(18,19)$. Thus, a treatment regime that targets both the early systemic and later kidney-specific effects of sepsis should have the highest likelihood of success. Microvascular dysfunction during sepsis is associated with poorer outcomes (31). In murine models of sepsis-induced AKI, reduced peritubular capillary perfusion is a 
relatively early event and precedes the loss of tubular brush border membrane $(6,8,21)$. Inhibition of the brush border metalloproteinases meprin A with actinonin, a naturally occurring hydroxamate found in actinomycetes and a potent inhibitor of meprin A (24), has been shown to be protective in renal ischemia/reperfusion- (11) and cisplatin-induced AKI, (10) and to preserve renal function when administered at the time of CLP (12). Thus, the goal of the present study was to evaluate the effects of actinonin on the renal tubular microenvironment during sepsis and to test its therapeutic potential when administered even after the onset of sepsis.

Following CLP in the mouse, cytokine levels increase during the first few hours (21) and are followed closely by a decline in peritubular capillary perfusion and an associated increase in cellular redox stress. Pretreatment with actinonin inhibited IL1- $\beta$ (but not TNF- $\alpha$ ) and prevented the early decline in capillary perfusion and tubular redox stress observed at $7 \mathrm{~h}$. At $18 \mathrm{~h}$ following pretreatment IL1- $\beta$ levels remained depressed and TNF- $\alpha$ levels were reduced but to a lesser extent. Peritubular capillary perfusion was still preserved, and signs of tubular injury were reduced. Interestingly, serum nitrate/nitrite levels were unchanged with actinonin administration suggesting that IL1- $\beta$ is not the major determinant of the increase in systemic NO generation. Based on these findings it is reasonable to attribute at least some of the protective effects of actinonin to inhibition of meprin A since meprin A can generate activated IL1- $\beta$ from pro-IL1- $\beta$ (16). Yura et al. (17) showed that meprin $\alpha$ (a subunit of meprin A) knockout mice had improved renal function and lower IL1- $\beta$ and TNF$\alpha$ levels compared to wild-type mice treated with LPS. This is consistent with our findings that at $18 \mathrm{~h}$ both IL1- $\beta$ and TNF- $\alpha$ levels were reduced and renal function was improved after pretreatment with actinonin.

Tubular RNS generation occurs following the initial decline in peritubular capillary perfusion after CLP (6). Intravital microscopy of the kidney during sepsis shows areas of increased tubular redox stress (NAD(P)H autofluorescence) and tubular RNS generation (rhodamine fluorescence) in tubules bordered by capillaries with reduced perfusion $(6,7)$. There is compelling evidence to suggest that reduced capillary perfusion leads to oxidant generation (27). In the kidney peritubular microenvironment, superoxide generation in the presence of NO produced by iNOS in the tubular epithelium fuels the generation of the RNS, peroxynitrite $(6,7)$. Although the mechanism of activation of meprin A during sepsis is unknown, one possible pathway to augment the local activation of meprin A may be through RNS generation because peroxynitrite has been shown to activate other matrix degrading enzymes such as MMP-2 (32). Since meprins are cable of degrading a wide variety of substrates that are major components of basement membranes and the extracellular matrix, such as collagen, laminin, fibronectin and nidogen $(10,13,15,33)$, activation of meprin A from the brush border membrane could damage both the peritubular capillary and the tubular epithelium. Loss of brush border membrane, cell sloughing and tubule vacuolization are morphological features of CLP-induced renal epithelial damage in the mouse $(6,21)$. Although actinonin is a relatively selective inhibitor of meprin A, actinonin has also been reported to inhibit MMP-2 at higher concentrations (34). Even through actinonin may have multiple substrates, its effects in the kidney are generally considered to be mediated by meprin inhibition because meprin A is responsible for the majority of extracellular matrix degrading activity in the mouse kidney $(13,14,23,24)$.

Actinonin has been shown previously to preserve renal function following CLP in the mouse when administered at the time of CLP and again at $6 \mathrm{~h}$ (12). We have extended those studies by examining the mechanism of protection and determining the effects of actinonin when administered after the onset of sepsis. $7 \mathrm{~h}$ post CLP was chosen for delayed treatment because this time is after the initial rise in cytokines and initial decline in renal capillary perfusion but before the generation of RNS in the kidney and the appearance of renal tubular 
epithelial damage $(6,21)$. The ability of actinonin to actually reverse peritubular capillary dysfunction and protect the kidney when administered $7 \mathrm{~h}$ after the onset of sepsis was striking. This supports the notion that preventing tubular injury may actually allow capillary perfusion to recover by interrupting the cycle of injury between peritubular capillaries and the tubular epithelium (5-7). As tubular swelling, cell sloughing, and membrane damage occur, peritubular capillary perfusion is likely impeded further. This would augment local hypoxia (35) and oxidant generation (7). This may explain how inhibiting meprin A not only reduced tubular damage but also partially reduced RNS generation by improving capillary perfusion. Actinonin did not affect systemic NO generation. Another agent, ethyl pyruvate, has been reported to inhibit kidney, muscle, and pancreas injury when administered as late as $12 \mathrm{~h}$ after CLP in mice (21). While the mechanisms of its protective effects are unknown, ethyl pyruvate is an oxidant scavenger (36).

\section{CONCLUSIONS}

The present studies demonstrate that actinonin inhibits the early IL1- $\beta$ release and the initial peritubular capillary dysfunction, as well as the subsequent tubular injury associated with CLP-induced sepsis in the mouse and suggest that the effects of actinonin may be related to inhibition of meprin A. These findings also suggest that agents like actinonin should be evaluated further as possible therapeutic agents because targeting both the early systemic and later kidney-damaging effects of sepsis should have the highest likelihood of success in septic patients.

\section{Acknowledgments}

This work was supported by the Nation Institutes of Health National Institute of Diabetes and Digestive and Kidney Diseases Grant DK075991 to PRM.

\section{REFERENCES}

1. Abraham E, Singer M. Mechanisms of sepsis-induced organ dysfunction. Crit Care Med. 2007:2408-2416. [PubMed: 17948334]

2. Remick DG. Pathophysiology of sepsis. Am J Pathol. 2007:1435-1444. [PubMed: 17456750]

3. Schrier RW, Wang W. Acute renal failure and sepsis. N Engl J Med. 2004:159-169. [PubMed: 15247356]

4. Russell JA. Management of sepsis. N Engl J Med. 2006:1699-1713. [PubMed: 17050894]

5. Tiwari MM, Brock RW, Kaushal GP, Mayeux PR. Disruption of renal peritubular blood flow in lipopolysaccharide-induced renal failure: role of nitric oxide and caspases. Am J Physiol Renal Physiol. 2005:F1324-F1332. [PubMed: 15998845]

6. Wu L, Gokden N, Mayeux PR. Evidence for the role of reactive nitrogen species in polymicrobial sepsis-induced renal peritubular capillary dysfunction and tubular injury. J Am Soc Nephrol. 2007:1807-1815. [PubMed: 17494883]

7. Wu L, Mayeux PR. Effects of the inducible nitric oxide synthase inhibitor L-N6-(1-iminoethyl)lysine on microcirculation and reactive nitrogen species generation in the kidney following lipopolysaccharide administration in mice. J Pharmacol Exp Ther. 2007:1061-1067. [PubMed: 17202403]

8. Wu L, Tiwari MM, Messer KJ, Holthoff JH, Gokden N, Brock RW, Mayeux PR. Peritubular capillary dysfunction and renal tubular epithelial cell stress following lipopolysaccharide administration in mice. Am J Physiol Renal Physiol. 2007:F261-F268. [PubMed: 16926442]

9. Sutton TA, Kelly KJ, Mang HE, Plotkin Z, Sandoval RM, Dagher PC. Minocycline reduces renal microvascular leakage in a rat model of ischemic renal injury. Am J Physiol. 2005:F91-F97.

10. Herzog C, Seth R, Shah SV, Kaushal GP. Role of meprin A in renal tubular epithelial cell injury. Kidney Int. 2007:1009-1018. [PubMed: 17377510] 
11. Takayama J, Takaoka M, Yamamoto S, Nohara A, Ohkita M, Matsumura Y. Actinonin, a meprin inhibitor, protects ischemic acute kidney injury in male but not in female rats. Eur J Pharmacol. 2008:157-163. [PubMed: 18093581]

12. Holly MK, Dear JW, Hu X, Schechter AN, Gladwin MT, Hewitt SM, Yuen PS, Star RA. Biomarker and drug-target discovery using proteomics in a new rat model of sepsis-induced acute renal failure. Kidney Int. 2006:496-506. [PubMed: 16760904]

13. Walker PD, Kaushal GP, Shah SV. Meprin A, the major matrix-degrading enzyme in the kidney produces a novel nitrogen fragment in vitro and in vivo. Kidney Int. 1998:1673-1680. [PubMed: 9607199]

14. Craig SS, Reckelhoff JF, Bond JS. Distribution of meprin in kidneys from mice with high- and low-meprin activity. Am J Physiol. 1987:C535-C540. [PubMed: 3310653]

15. Kaushal GP, Walker PD, Shah SV. An old enzyme with a new function: purification and characterization of a distinct matrix-degrading metalloproteinase in rat kidney cortex and its identification as meprin. J Cell Biol. 1994:1319-1327. [PubMed: 8063866]

16. Herzog C, Haun RS, Kaushal V, Mayeux PR, Shah SV, Kaushal GP. Meprin A and meprin alpha generate biologically functional IL-1beta from pro-IL-1beta. Biochem Biophys Res Comm. 2009:904-908. [PubMed: 19135030]

17. Yura RE, Bradley SG, Ramesh G, Reeves WB, Bond JS. Meprin A metalloproteases enhance renal damage and bladder inflammation after LPS challenge. Am J Physiol Renal Physiol. 2009:F135F144. [PubMed: 18971209]

18. Dudley C. Maximizing renal preservation in acute renal failure. BJU Int. 2004:1202-1206. [PubMed: 15613164]

19. Annane D, Bellissant E, Cavaillon JM. Septic shock. Lancet. 2005:63-78. [PubMed: 15639681]

20. Baker CC, Chaudry IH, Gaines HO, Baue AE. Evaluation of factors affecting mortality rate after sepsis in a murine cecal ligation and puncture model. Surgery. 1983:331-335. [PubMed: 6879447]

21. Miyaji T, Hu X, Yuen PS, Muramatsu Y, Iyer S, Hewitt SM, Star RA. Ethyl pyruvate decreases sepsis-induced acute renal failure and multiple organ damage in aged mice. Kidney Int. 2003:1620-1631. [PubMed: 14531793]

22. Hollenberg SM. Mouse models of resuscitated shock. Shock. 2005:58-63. [PubMed: 16374374]

23. Bertenshaw GP, Turk BE, Hubbard SJ, Matters GL, Bylander JE, Crisman JM, Cantley LC, Bond JS. Marked differences between metalloproteases meprin A and B in substrate and peptide bond specificity. J Biol Chem. 2001:13248-13255. [PubMed: 11278902]

24. Kruse MN, Becker C, Lottaz D, Kohler D, Yiallouros I, Krell HW, Sterchi EE, Stocker W. Human meprin alpha and beta homo-oligomers: cleavage of basement membrane proteins and sensitivity to metalloprotease inhibitors. Biochem J. 2004:383-389. [PubMed: 14594449]

25. Carmago S, Shah SV, Walker PD. Meprin, a brush-border enzyme, plays an important role in hypoxic/ischemic acute renal tubular injury in rats. Kidney Int. 2002:959-966. [PubMed: 11849450]

26. Gomes A, Fernandes E, Lima JL. Use of fluorescence probes for detection of reactive nitrogen species: a review. J Fluoresc. 2006:119-139. [PubMed: 16477509]

27. Paxian M, Keller SA, Cross B, Huynh TT, Clemens MG. High-resolution visualization of oxygen distribution in the liver in vivo. Am J Physiol Gastrointest Liver Physiol. 2004:G37-G44. [PubMed: 12829437]

28. Wunder C, Brock RW, Krug A, Roewer N, Eichelbronner O. A remission spectroscopy system for in vivo monitoring of hemoglobin oxygen saturation in murine hepatic sinusoids, in early systemic inflammation. Comp Hepatol. 2005

29. Wang W, Faubel S, Ljubanovic D, Mitra A, Kim J, Tao Y, Soloviev A, Reznikov LL, Dinarello CA, Schrier RW, Edelstein CL. Endotoxemic acute renal failure (ARF) is attenuated in caspase-1 deficient mice. Am J Physiol Renal Physiol. 2005:F997-F1004. [PubMed: 15644489]

30. Remick DG, Newcomb DE, Bolgos GL, Call DR. Comparison of the mortality and inflammatory response of two models of sepsis: lipopolysaccharide vs. cecal ligation and puncture. Shock. 2000:110-116. [PubMed: 10670840]

31. Vincent JL, De Backer D. Microvascular dysfunction as a cause of organ dysfunction in severe sepsis. Critical Care. 2005:S9-S12. [PubMed: 16168075] 
32. Okamoto T, Akaike T, Sawa T, Miyamoto Y, van der Vliet A, Maeda H. Activation of matrix metalloproteinases by peroxynitrite-induced protein S-glutathiolation via disulfide S-oxide formation. J Biol Chem. 2001:29596-29602. [PubMed: 11395496]

33. Walker PD, Kaushal GP, Shah SV. Presence of a distinct extracellular matrix-degrading metalloproteinase activity in renal tubules. J Am Soc Nephrol. 1994:55-61. [PubMed: 7948783]

34. Sina A, Lord-Dufour S, Annabi B. Cell-based evidence for aminopeptidase N/CD13 inhibitor actinonin targeting of MT1-MMP-mediated proMMP-2 activation. Cancer Lett. 2009:171-176. [PubMed: 19264392]

35. Yasuda H, Yuen PS, Hu X, Zhou H, Star RA. Simvastatin improves sepsis-induced mortality and acute kidney injury via renal vascular effects. Kidney Int. 2006:1535-1542. [PubMed: 16557230]

36. Reade MC, Fink MP. Bench-to-bedside review: Amelioration of acute renal impairment using ethyl pyruvate. Critical Care. 2005:556-560. [PubMed: 16356237] 


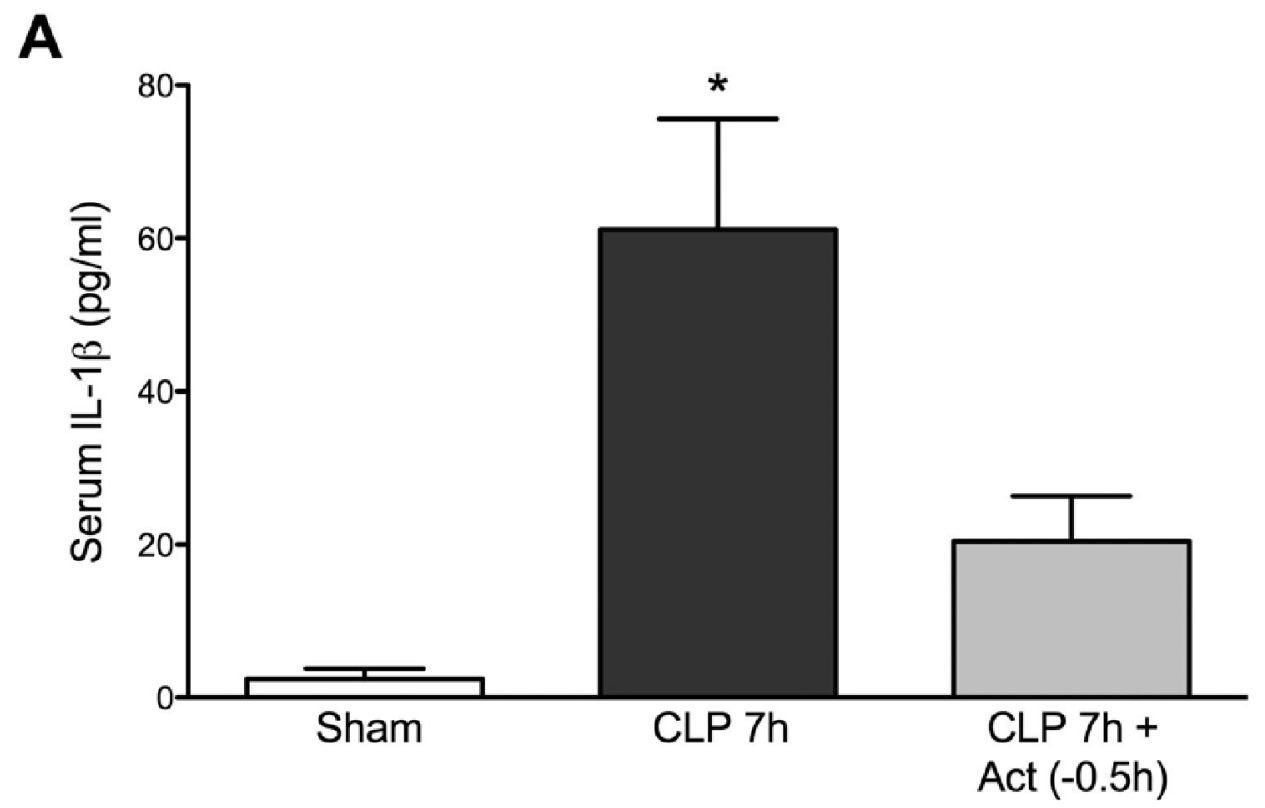

B

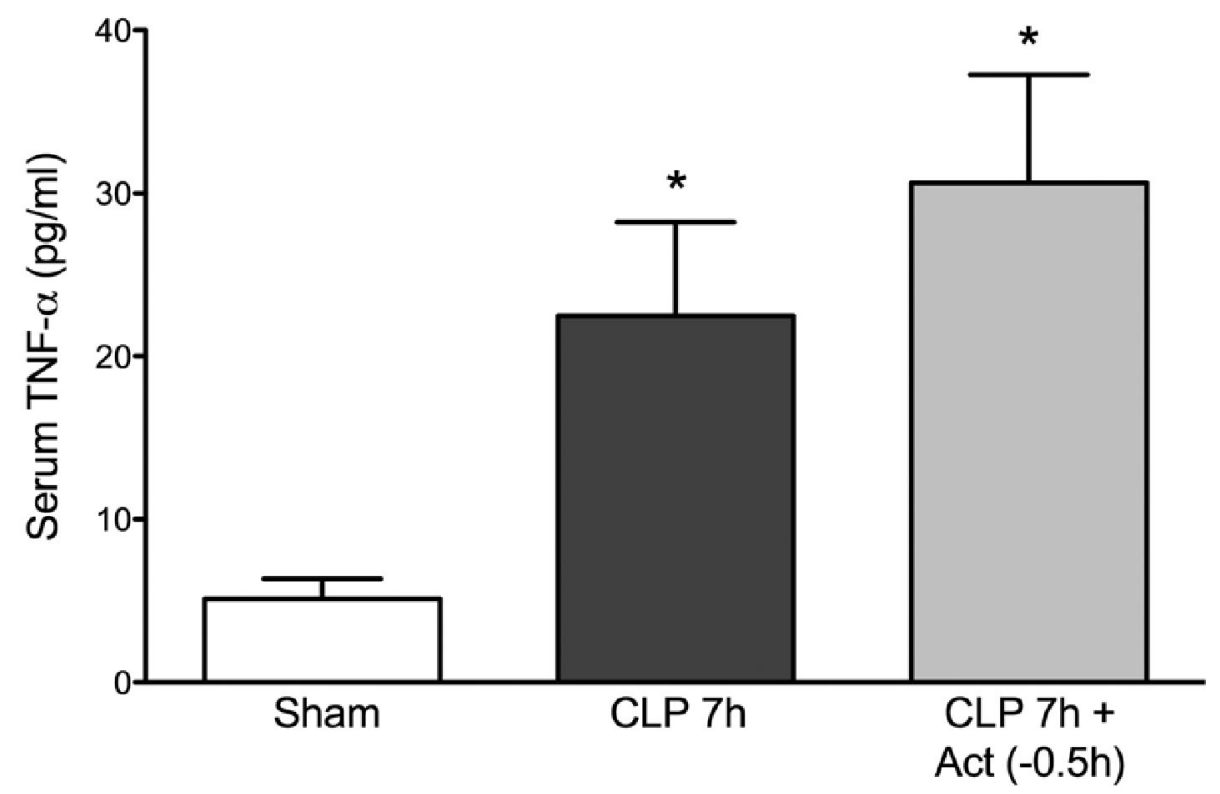

Fig. 1.

Effects of actinonin on serum IL-1 $\beta(A)$ and TNF- $\alpha(B)$ levels at $7 \mathrm{~h}$ post CLP. At $7 \mathrm{~h}$ post CLP serum levels of both IL-1 $\beta$ and TNF- $\alpha$ levels were increased compared with the Sham group. Treatment with actinonin $0.5 \mathrm{~h}$ prior to CLP significantly reduced serum levels of IL-1 $\beta$ only. Panel A: $* P<0.05$ compared with Sham and CLP $7 \mathrm{~h}+$ Act $(-0.5 \mathrm{~h})$. Panel B: $* P<0.05$ compared too Sham. Data are mean \pm S.E.M. ( $n=4-6$ per group). 


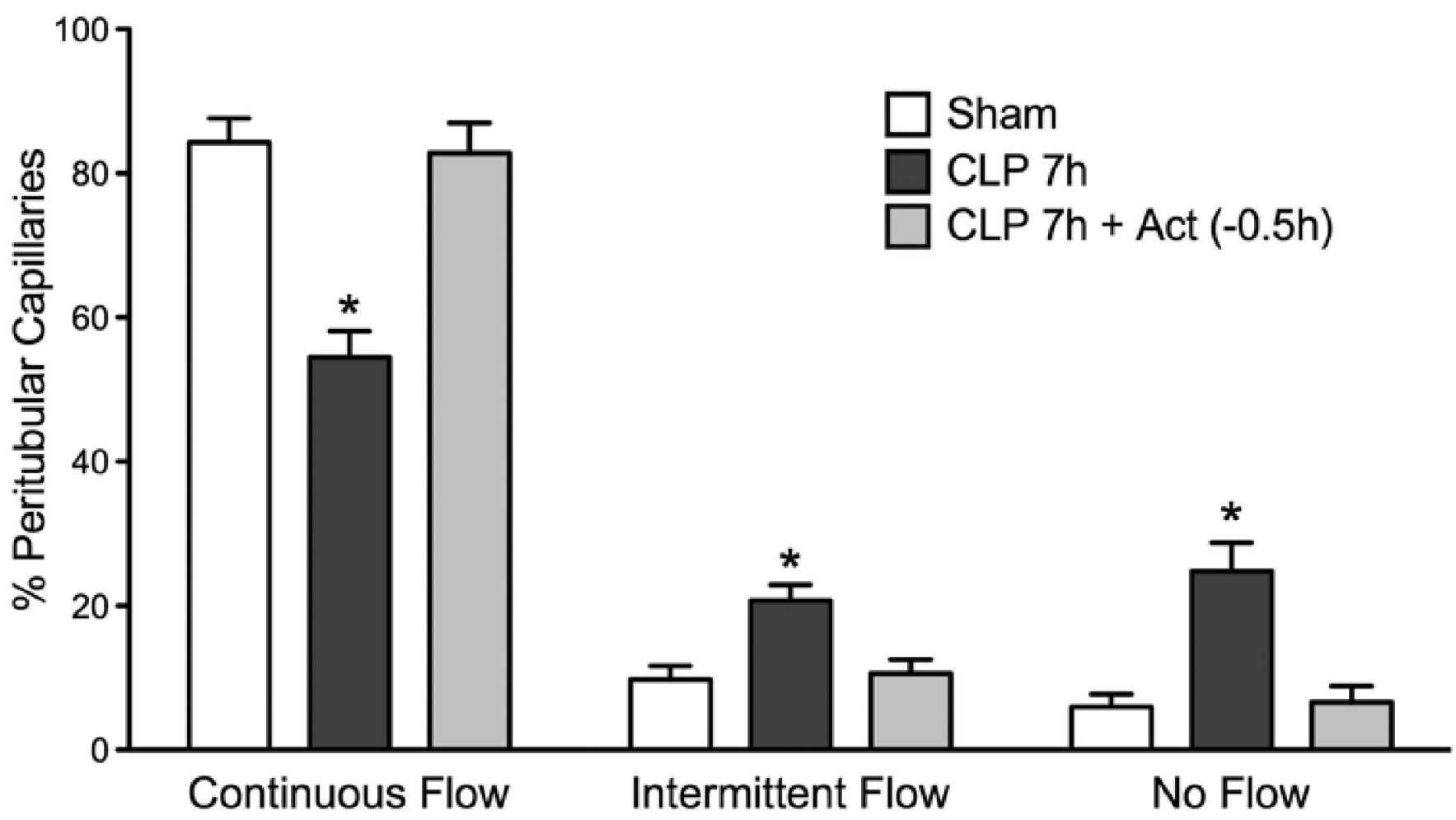

Fig. 2.

Effects of actinonin on CLP-induced disruption of renal cortical peritubular capillary perfusion at $7 \mathrm{~h}$ post CLP. Renal cortical capillaries were classified into capillaries with continuous, intermittent or no flow. At $7 \mathrm{~h}$ the percentage of capillaries with continuous flow was significantly decreased $(* P<0.05$ compared with Sham) and the percentage of capillaries with intermittent or no flow was significantly increased ( $* P<0.05$ compared with Sham). Actinonin treatment at $0.5 \mathrm{~h}$ prior to CLP prevented the changes in renal capillary perfusion. ${ }^{*} P<0.05$ compared with Sham and CLP $7 \mathrm{~h}+$ Act $(-0.5 \mathrm{~h})$. Data are mean \pm S.E.M $(n=7$ per group) . 


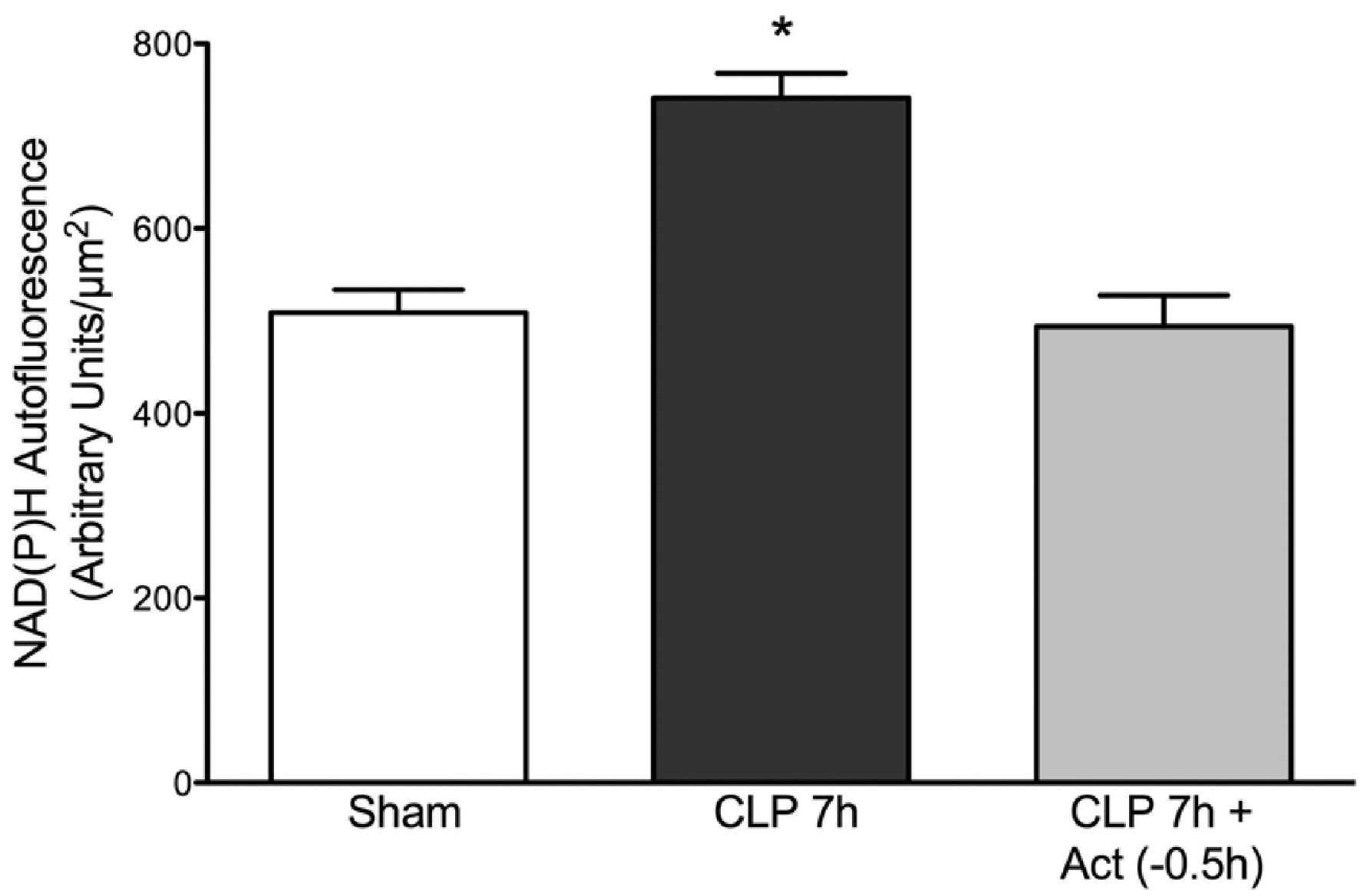

Fig. 3.

Effects of actinonin on renal tubular cell redox stress at $7 \mathrm{~h}$ post CLP. NAD(P)H autofluorescence intensity was measured as an indicator of tubular cell redox stress. Treatment with actinonin $0.5 \mathrm{~h}$ prior to CLP significantly reduced cellular NAD $(\mathrm{P}) \mathrm{H}$ autofluorescence levels at $7 \mathrm{~h}$ post CLP. $* P<0.05$ compared to Sham and CLP $7 \mathrm{~h}+$ Act $(-0.5$ h). Data are mean \pm S.E.M. $(n=6-7$ per group $)$. 


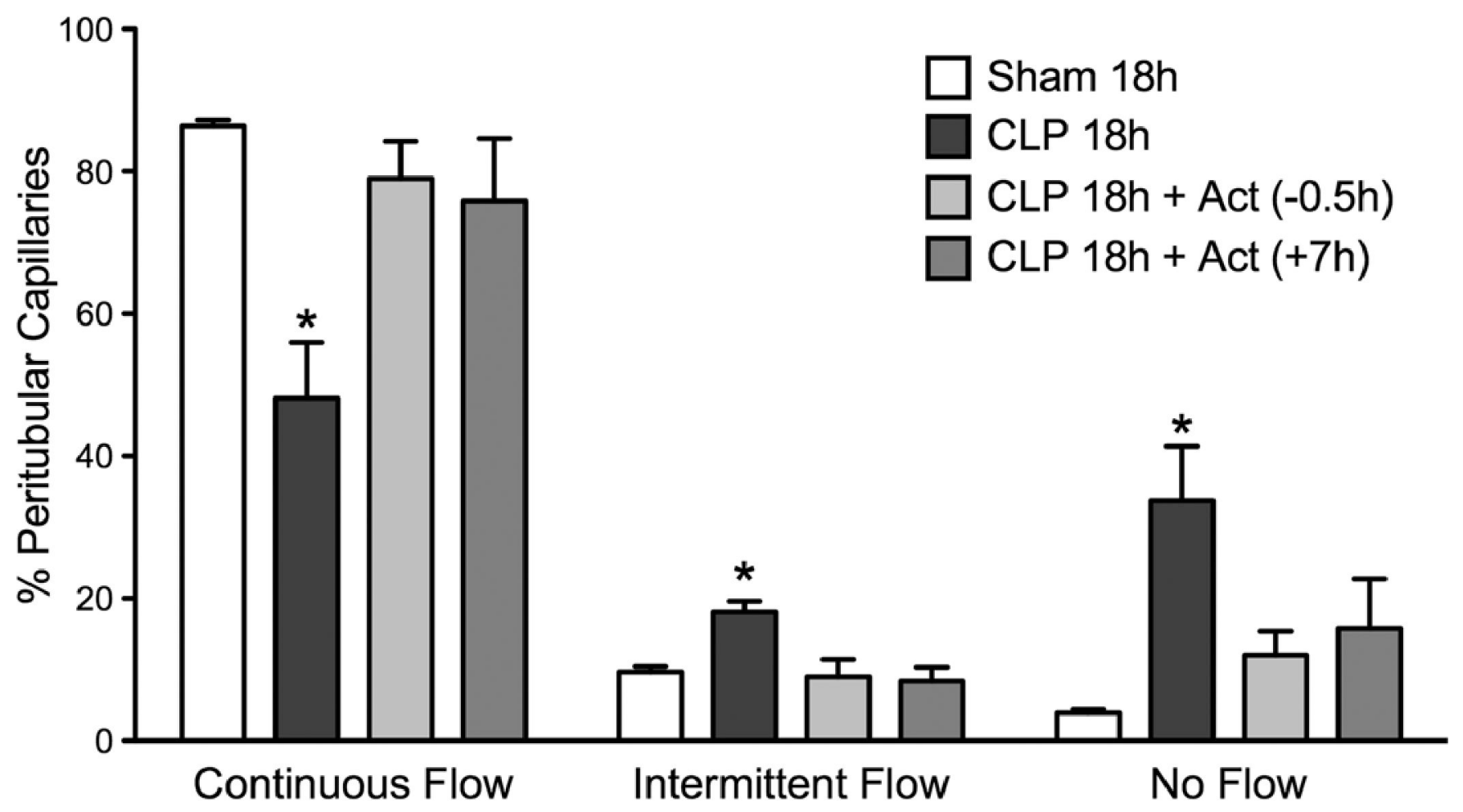

Fig. 4.

Effect of actinonin on CLP-induced disruption of renal cortical peritubular capillary perfusion at $18 \mathrm{~h}$ post CLP. The percentage of capillaries with continuous flow was significantly decreased $(* P<0.05$ compared with Sham $18 \mathrm{~h}$ and all other groups) and the percentage of capillaries with intermittent or no flow was significantly increased $\left({ }^{*} P<0.05\right.$ compared with Sham $18 \mathrm{~h}$ and all other groups). Actinonin treatment at $0.5 \mathrm{~h}$ prior to CLP surgery $($ CLP $18 \mathrm{~h}+\operatorname{Act}(0.5 \mathrm{~h}))$ or $7 \mathrm{~h}$ post CLP surgery (CLP $18 \mathrm{~h}+$ Act $(+7 \mathrm{~h}))$ prevented the fall in renal capillary perfusion. Data are mean \pm S.E.M. ( $n=7$ per group). 

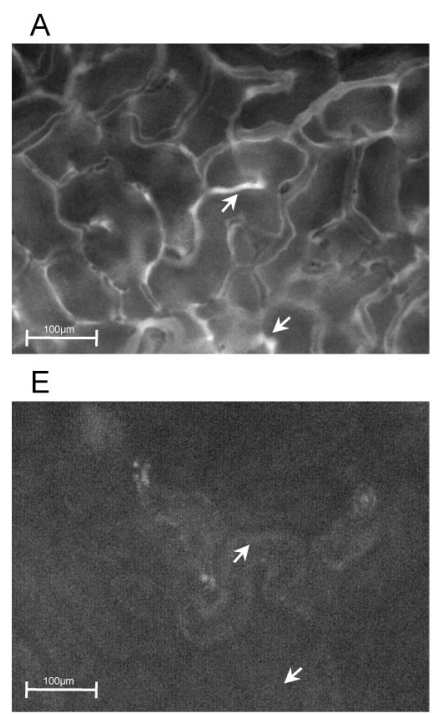

B

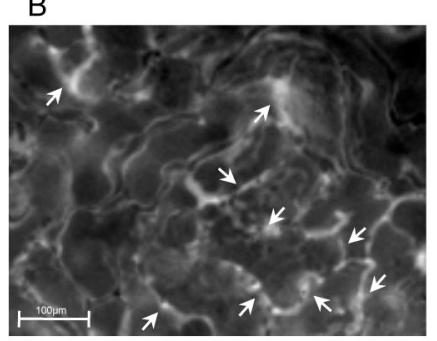

$\mathrm{F}$

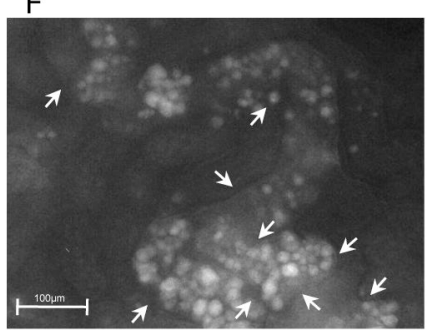

C

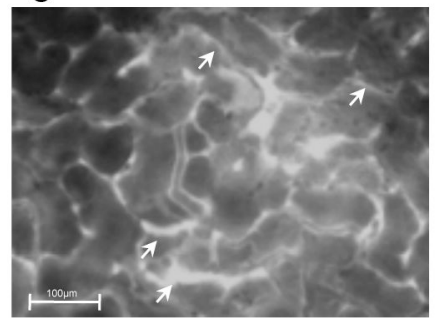

G

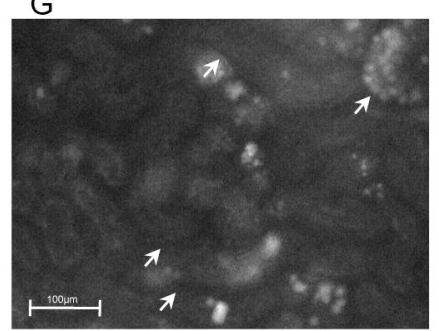

$\mathrm{D}$

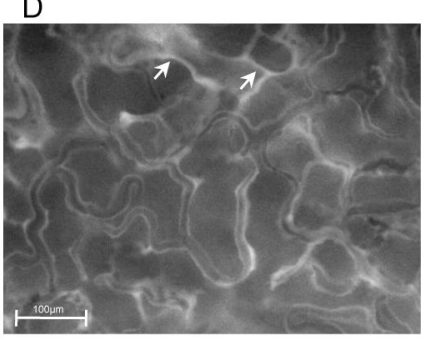

$\mathrm{H}$

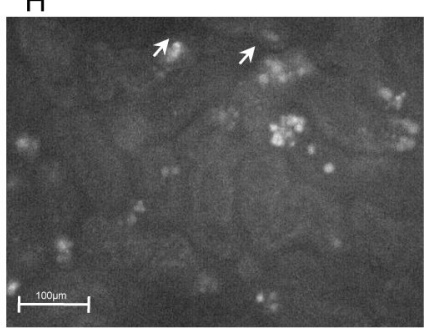

Fig. 5.

Representative images captured during IVVM. Shown are images of FITC-dextran (capillary perfusion, $A-D$ ) and rhodamine fluorescence (RNS generation, $E-H$ ) captured from the same field view from Sham 18h $(A, E)$, CLP 18h $(B, F)$, CLP $18 \mathrm{~h}+$ Act $(-0.5 \mathrm{~h})$ $(C, G)$ and CLP $18 \mathrm{~h}+$ Act $(+7 \mathrm{~h})(D, H)$. Capillaries with continuous flow appear darker because of rapidly flowing red blood cells, which obscure the FITC-dextran fluorescence. Arrows indicate capillaries with intermittent or no flow. Original magnification, 200x. 


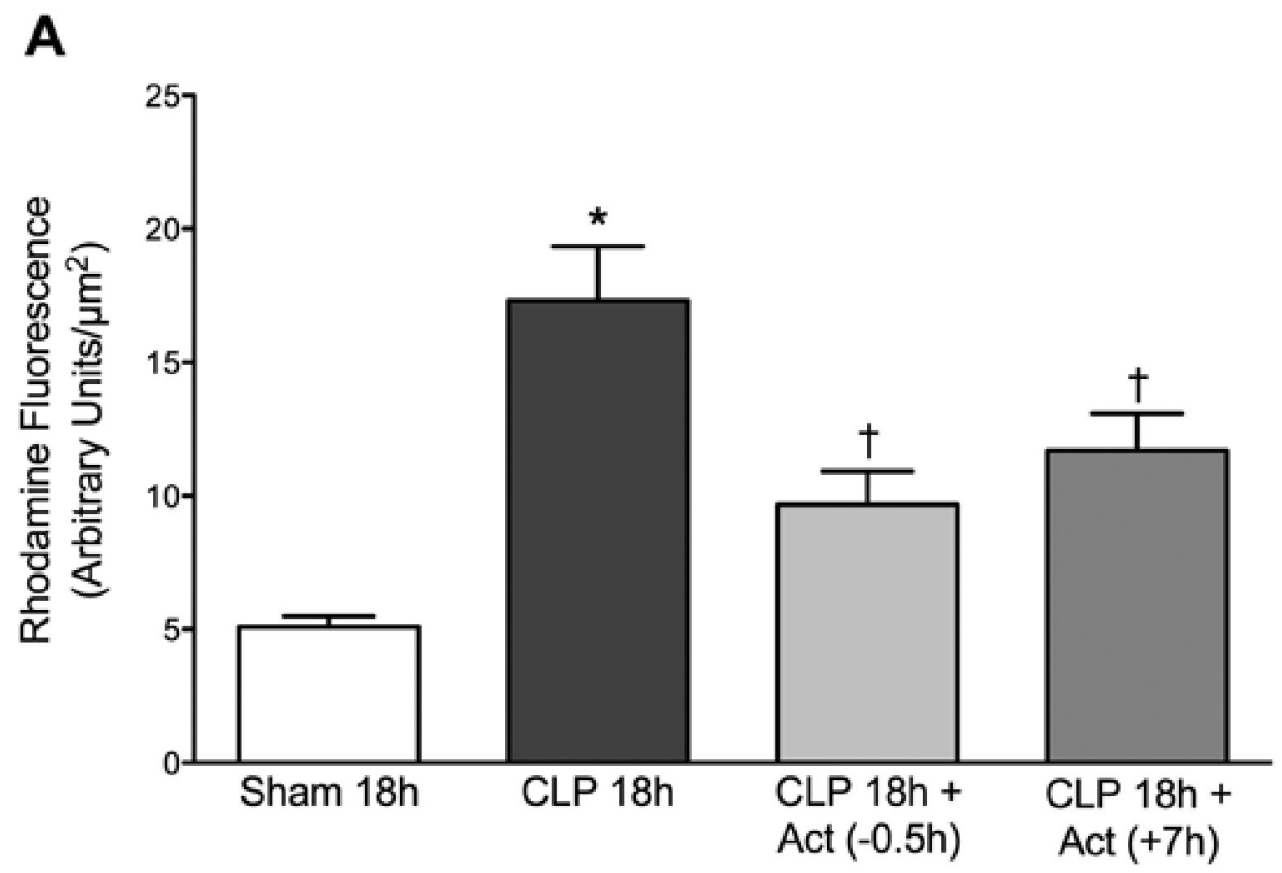

B

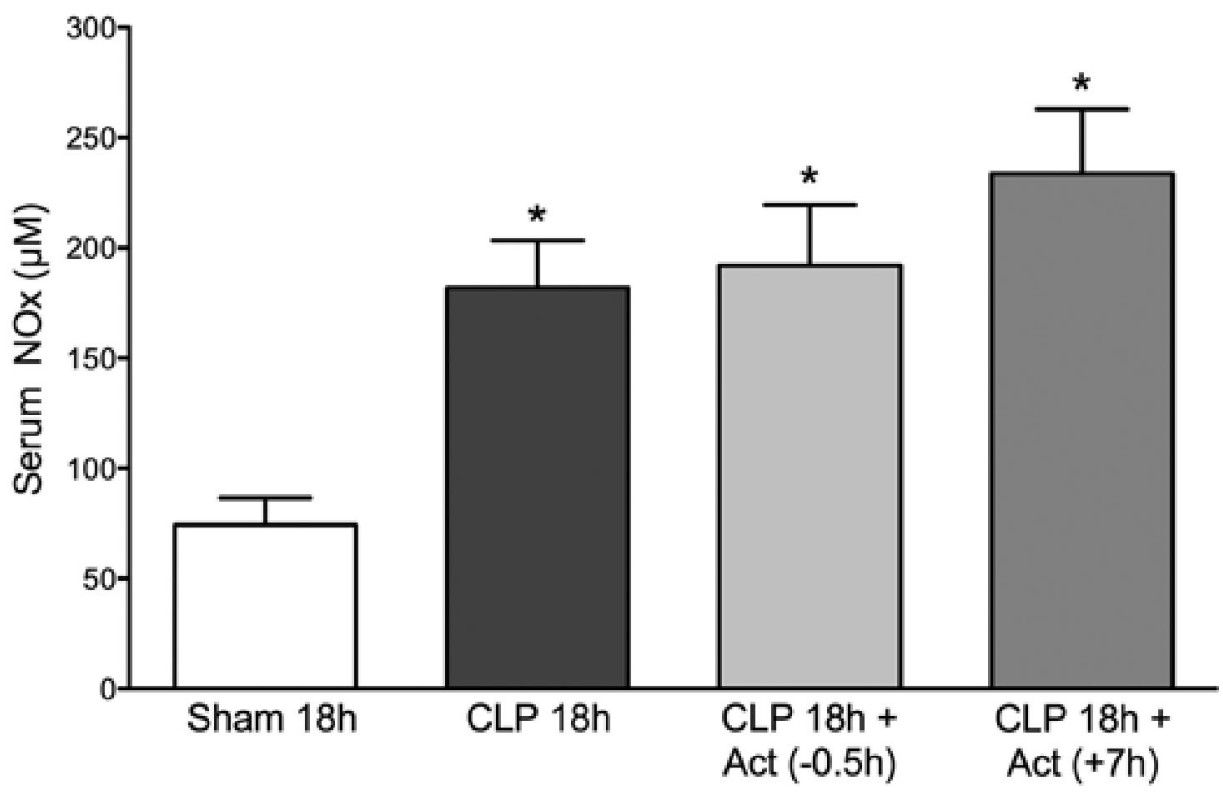

Fig. 6.

Effects of actinonin on CLP-induced renal tubular RNS generation $(A)$ and serum nitrate/ nitrite (NOx) levels $(B)$ at $18 \mathrm{~h}$ post CLP-induced sepsis. Rhodamine fluorescence was used as an indicator of RNS generation. Significant elevation in rhodamine fluorescence was detected at $18 \mathrm{~h}$ post CLP. Treatment with actinonin $0.5 \mathrm{~h}$ prior to or $7 \mathrm{~h}$ post CLP prevented the increase in rhodamine fluorescence. (Panel A: $* P<0.05$ compared with all other groups). Serum NOx levels were significantly elevated at CLP $18 \mathrm{~h}$ group. Actinonin did not alter serum NOx levels when administered at $0.5 \mathrm{~h}$ prior to or $7 \mathrm{~h}$ post CLP (Panel B: $* P<$ 0.05 compared with Sham $18 \mathrm{~h}$ ). Data are mean \pm S.E.M. ( $\mathrm{n}=7$ per group). 
A

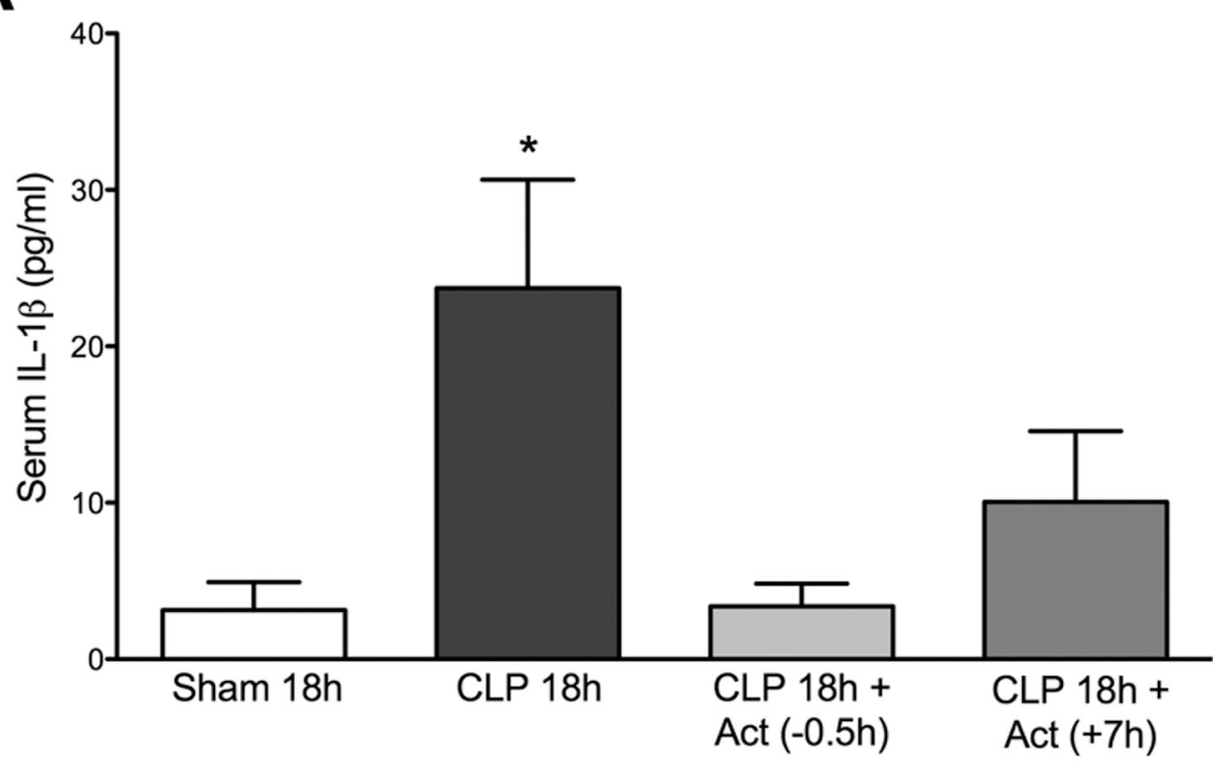

B

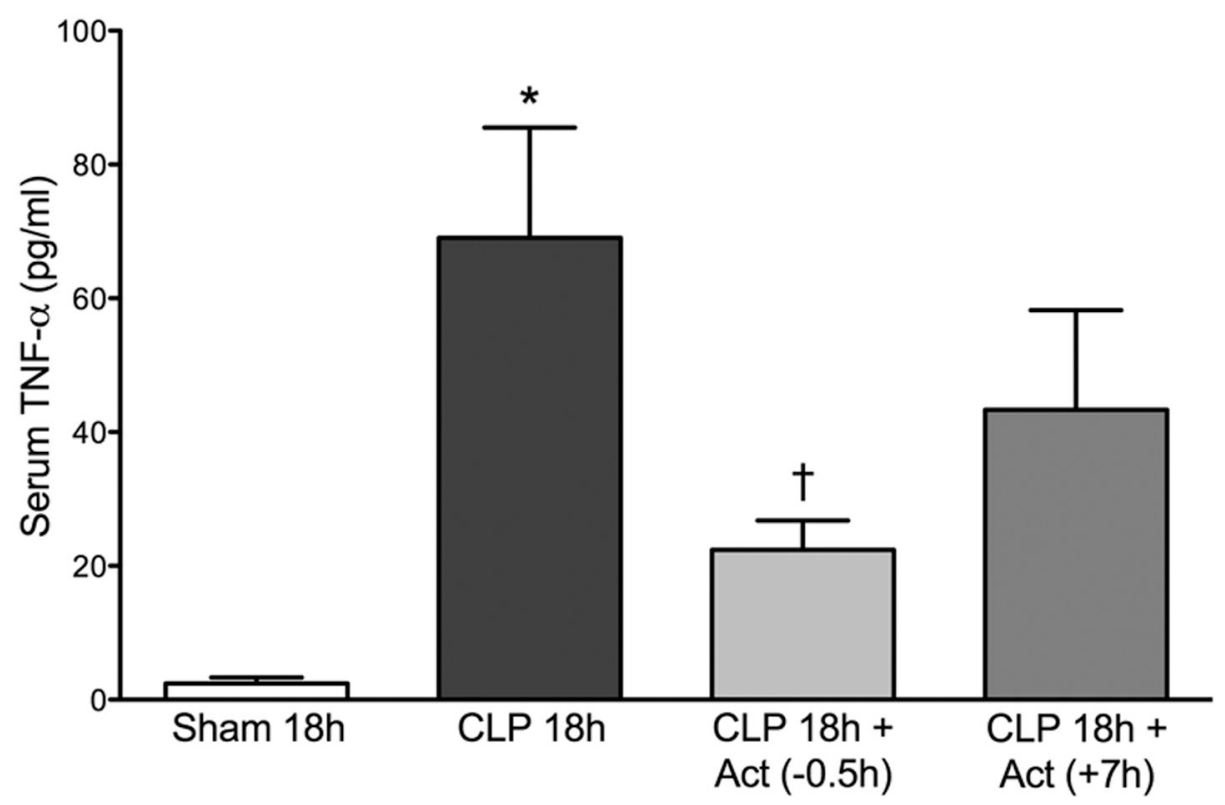

Fig. 7.

Effects of actinonin on serum IL-1 $\beta(A)$ and TNF- $\alpha(B)$ levels at $18 \mathrm{~h}$ post CLP. At $18 \mathrm{~h}$ post CLP both IL- $1 \beta$ and TNF- $\alpha$ were increased compared to the Sham group. Treatment with actinonin $0.5 \mathrm{~h}$ prior to or $7 \mathrm{~h}$ post CLP significantly reduced serum levels of IL-1 $\beta$. Panel $A: * P<0.05$ compared with all other groups. Only treatment with actinonin $0.5 \mathrm{~h}$ prior to CLP significantly reduced the serum TNF- $\alpha$ levels. Panel B: $* \mathrm{P}<0.05$ compared with Sham $18 \mathrm{~h}$; ${ }^{\dagger} P<0.05$ compared with CLP $18 \mathrm{~h}$. Data are mean \pm S.E.M. ( $\mathrm{n}=6-7$ per group). 
A

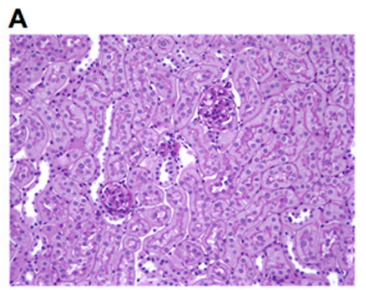

C

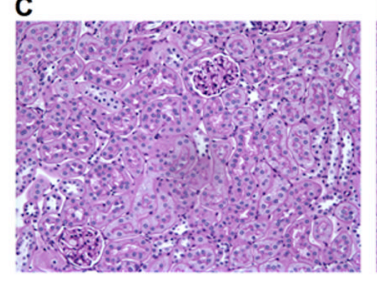

B

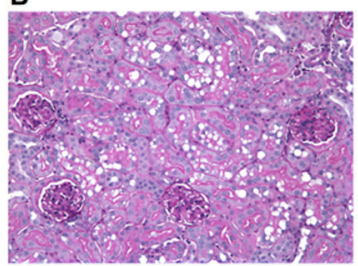

D

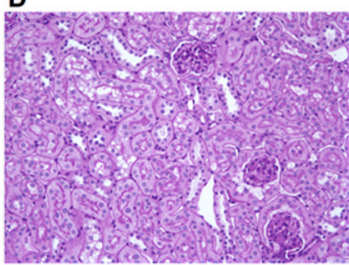

E

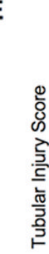

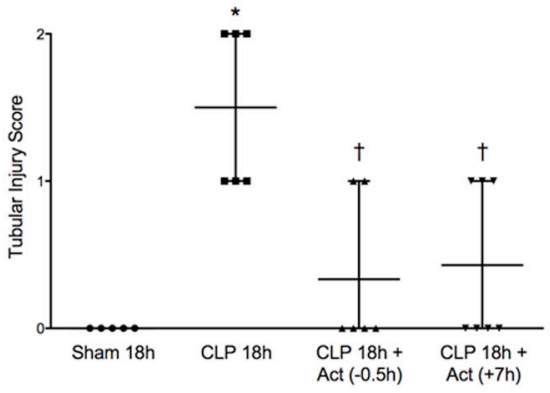

F

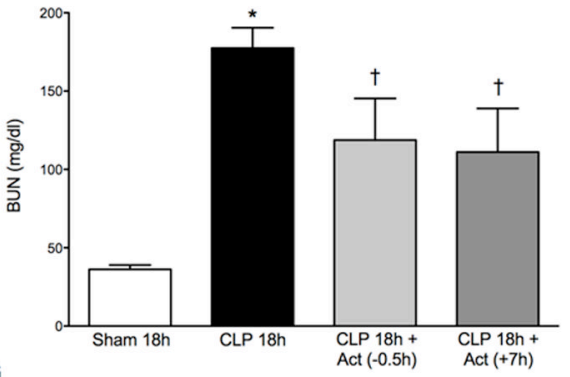

G

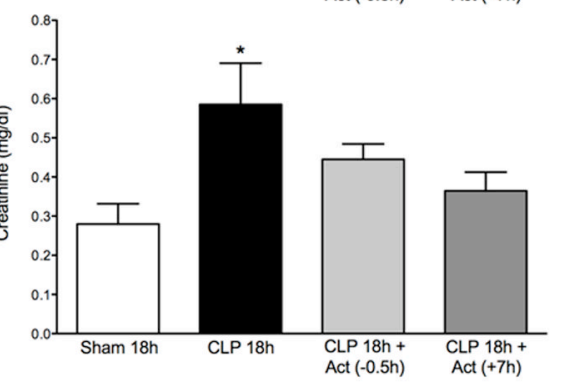

Fig. 8.

Effects of actinonin on kidney morphology and renal function. Representative PAS-stained kidney sections from Sham 18h (A), CLP 18h (B), CLP 18h + Act $(-0.5 \mathrm{~h})(C)$, and CLP 18h $+\operatorname{Act}(+7 \mathrm{~h})(D)$ are shown. CLP $(B)$ caused mild brush border loss, tubular degeneration, and vacuolization in the early segments of proximal tubules at $18 \mathrm{~h}$ post CLP (original magnification of 200x). Fewer histological changes were observed in the groups treated with actinonin $0.5 \mathrm{~h}$ before CLP $(C)$ or $7 \mathrm{~h}$ post CLP $(D)$. Semi-quantitative morphological injury scoring $(E)$ showed reduced morphological changes in groups treated with actinonin at $0.5 \mathrm{~h}$ prior to or $7 \mathrm{~h}$ post CLP (Panel $E$ : ${ }^{*} P<0.05$ compared to all other groups; ${ }^{*} P<0.05$ compared to Sham $18 \mathrm{~h}$ and CLP $18 \mathrm{~h}$. Data are plotted as individual values with mean and 
range ( $n=5-7$ per group). Serum BUN levels, a marker of renal function, were significantly elevated at $18 \mathrm{~h}$ post CLP. Both treatment regimens with actinonin partially but significantly reduced serum levels of BUN, indicating that actinonin improved renal function (Panel F : $* P<0.05$ compared to all other groups; $=P<0.05$ compared to Sham $18 \mathrm{~h}$ and CLP $18 \mathrm{~h}$ ). Serum creatinine levels, a more specific marker of renal function, were significantly elevated by $18 \mathrm{~h}$ post CLP. Delayed treatment with actinonin significantly reduced serum creatinine concentration also indicating improved renal function (Panel G: $* \mathrm{P}<0.05$ compared to Sham and CLP $18 \mathrm{~h}+$ Act $(+7 \mathrm{~h}))$. Data are mean \pm S.E.M.; $\mathrm{n}=6-7$ (Panel F) and $\mathrm{n}=7-9($ Panel $G)$. 